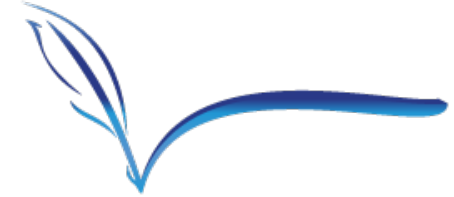

SSAD

Stratejik ve Sosyal Araştırmalar Dergisi

ISSN 2587-2621

Cilt 5, Türk-Yunan İlişkileri Özel Sayısı | Volume 5, Special Issue: Turkish-Greek Relations, 30 Ağustos/30 August 2021

sisaddergi@gmail.com

Makale Türü/Article Type: Araştırma/Research

Makale Gönderim Tarihi/Received Date: 06.07.2021

Makale Kabul Tarihi/Accepted Date: 26.08.2021

DOI: $10.30692 /$ sisad.963215

\title{
ORAL MEMORIES AND THE CRETAN IDENTITY OF CRETAN TURKS IN BODRUM, TURKEY
}

\author{
Bodrum'daki Giritli Türklerin Sözlü Hatıraları ve Girit Kimliği \\ Eleni PSARADAKI \\ Ph. D. \\ University of Crete \\ Social Antropology \\ ORCID ID: 0000-0003-1708-758X \\ e.psaradaki@yahoo.gr
}

Atıf/Citation: Eleni Psaradaki (2021), "Oral Memories and the Cretan Identity Of Cretan Turks in Bodrum, Turkey", Stratejik ve Sosyal Araştırmalar Dergisi Türk-Yunan Ilişskileri Özel Sayısı, C. 5, 30 Ağustos 2021, s.41-54.

\begin{abstract}
This study constitutes an analysis of narratives of descendants of Cretan Turks, regarding the memories from their homelands, through material which has been collected from the case studies of Bodrum in Turkey. It is based on material collected from field research and interviews between 2013-2016, and also data from newspapers and scientific literature related to the issue of refugees, in which we encounter references to the practices of their population group. The study also focuses on the ways in which the concept of "Cretan" identity is preserved in oral memories and narrations, in a social environment that diversity was not accepted for many years. Hence, this paper constitutes a presentation of the case study of Cretan Turks in Bodrum and focuses on the views of memory and identity which are held at the present. Phrases like "I am Cretan" and nicknames which are used from narratives still show that the Cretan Turks in Bodrum continue to express their double identity through their oral memories by keeping the past alive.
\end{abstract}

Keywords: Population Exchange, Cretan Turks, oral memory, identity.

Öz: Bu çalışma, Türkiye'deki Bodrum vaka çalışmalarından derlenen materyaller aracılığıyla Girit Türklerinin soyundan gelenlerin anavatanlarından hatıralarına ilişkin anlatılarının bir analizini oluşturmaktadır. 2013-2016 yılları arasında saha araştırması ve röportajlardan toplanan materyallere ve ayrıca nüfus gruplarının uygulamalarına referanslarla karşılaştığımız mülteciler konusuyla ilgili gazete ve bilimsel literatürdeki verilere dayanmaktadır. Çalışmada ayrıca, yıllardır çeşitliliğin kabul edilmediği bir toplumsal ortamda, Girit kimliği kavramının sözlü hatıralarda ve anlatılarda nasıl korunduğuna da odaklanılmaktadır. Bu nedenle, bu makale Bodrum'daki Girit Türklerinin vaka çalışmasının bir sunumunu teşkil etmekte ve günümüzde tutulan Girit hafızası ve kimliğine ilişkin görüşlere odaklanmaktadır. Anlatılarda kullanılan "Ben Giritliyim” gibi lakaplar, Bodrum'daki Girit Türklerinin geçmişi yaşatarak ikili kimliklerini sözlü hatıralarıyla ifade etmeye devam ettiklerini ortaya çıkarmaktadır.

Anahtar Kelimeler: Mübadele, Giritli Türkler, sözlü hafiza, kimlik. 


\section{INTRODUCTION}

This publication constitutes an analysis of data which has been collected from the case studies of Cretan Turks, after ethnological field work in the city of Bodrum, Turkey, in the context of doctoral studies ${ }^{1}$. This research attempts to answer questions about whether the Muslim refugees, who formed a separate part of the history of Crete and left the island during the Population Exchange (1923), passed on to their descendants' information, pertaining to the Cretan origin and how this information was preserved over time.

With the term "Cretan Turks" we refer to the descendants of Islamized Cretans during the occupation of the island of Crete by the Turks in 1669. A large number of Cretans (as it also happened generally in Greece) became Muslims in order to avoid the socioeconomic hardships of the Ottoman Occupation of Crete. They lived in different areas of the island and were mainly engaged in agricultural, livestock and commercial activities while a few of them also held administrative positions (e.g., Chalkiadakis, 2003, pp 350-351).

During revolutions periods in Crete, the biggest taking place in 1898, Cretan Turks began to migrate internally in Crete, leaving their homes in the villages in order to move to larger urban areas in the island. In 1923, during the Population Exchange which was the most organized departure, the last Cretan Turks migrated in Turkey. In particular, a total of 23,821 Muslims left Crete. (e. g., Limantzakis, 2015, p 114).

The city of Bodrum was chosen for the purpose of the case study, because refugees of Asia Minor left this place during the Population Exchange and founded the settlement of Nea Alikarnassos in Heraklion. In an earlier postgraduate thesis ${ }^{2}$ the memories of the refugees' homelands and their special identity have been studied. During that research study, the need of the descendants of Asia Minor to maintain their unique tradition through music, dance, song and food was reported through interviews. The desire of the people of Asia Minor to connect the two places resulted in: a) the choice of the settlement name as "Nea Alikarnassos", b) the decision to establish a football team called "Herodotus" and c) the rebuilding of the church of Agios Nikolaos, as was the name of the church at their place of origin.

Based on the above, the research of this study started in order to find if there were similarities between these two social groups, the Cretan Turks and the Asia Minor refugees. In particular, it was investigated if they experienced similar struggles and difficulties in the place of settlement and if Cretan Turks, similar to the Asia Minor refugees in Greece, have maintained a distinct identity at present, in a public or private context.

Since there was no similar research on Cretan Turks in Greece, it was important not to approach the case study only through bibliography, but through field observation and interviews with descendants of Cretan Turks. The aim was to find out what the narrators remember and know about their origin and antecedents' life in Crete. In particular, the methods with which the memories of Cretan Turks refugees have been transferred to their descendants were studied as well as the image of the past, as it has been formed over time. Having these questions in mind, the field research in Bodrum started in the summer of 2013 and the first interviews were conducted in Turkish language with men and women, who were descendants of second, third and fourth generation of Cretan Turks (32 interviews, 15 with men and 17 with women. 19 were second generation Cretan Turks, 8 were third generation Cretan Turks and 5 were fourth generation Cretan Turks).

The questions were about habits which appear to Cretan Turks in connection to Crete in daily life and also about the use of Cretan dialect from them at the present time. The technique, which was

\footnotetext{
${ }^{1}$ Psaradaki 2020

${ }^{2}$ Psaradaki 2012
} 
chosen for the interviews, as the most appropriate for the purpose of the case study, was the semistructured interviews and their analysis strategy was a thematic analysis. The reason for choosing semi-structured interviews was the exploratory nature of the research. The aim was to relate memories with specific areas of daily life. All interviews took place at houses or workplaces of Cretan Turks at "Kumbahçe Mahallesi" (Kumbahçe neighborhood) and a tape recorder was used during the interviews. Our work at the "Bodrum Museum of Underwater Archeology" with Erasmus Program helped me to get familiar with the social environment of Cretan Turks and get in touch with them more easily.

During the case study, it was found out that many Cretan Turks learn about Crete from books which were suggested to me. These books were the "Dalavera Memet'in Bodrum Tarihi" (The story of Bodrum from Dalavera Memet) by Baskın Oran - Feyhan Görgün (2009), which was concerned with the life of Mehmet Özgüreli a man of Cretan origin lived in Bodrum. In the book it seems like he answers questions about life in Bodrum, according to him and his family experiences. Another book was "Karşı Kiyılardan Bodrum'a" (From the Opposite Coast to Bodrum) by Belkis Öztin Koparanoğlu (2006), in which the author describes how life was in Bodrum, while she lived in the Cretan neighborhood. At the end of the book, food recipes and photos of Turkish Cretans are presented.

Apart from these books about Bodrum, Cretan Turks mentioned literature, that include family stories during the Population Exchange between Greece and Turkey. Books like these are translated in Greek language too. For example, "Kritimu, Giritim Benim" (My Crete) by Altınsay (2008) and "Savaşın Çocukları" (Childen of the War) by Yorulmaz (2005).

Although, we recognize the difficulty of researching about the issue of Cretan Muslims after the Population Exchange, as there are no statistics or survey data from that period (Andriotis, Izbek 2005: 346-7). Recently, there have been many studies in Turkey about Cretan Turks. For example, studies as Akça 2011, Bayındır Goularas 2012, Baykara 2010, Bedlek 2016, Çapa 2011, Çokişler 2007, Erkal 2008, Güler 2011, Kodal 2008, Konya 2013, Koparanoğlu 2006, Oran- Görgün 2004, Sepetcioğlu 2007, 2010, Şenesen 2012. Research indicates that the Cretan Turks in Turkey were engaged mainly in trade and manual labour. Despite the many difficulties people faced and their settlement in separate neighborhoods in the cities and villages of the Turkish countryside, Cretan Turks achieved to create their lives again.

In Turkish bibliography, it is pointed out that the refugees, with their settlement in Turkey, transferred their social customs, traditions, music, eating habits and their language. Thus, Cretan Turks in this way gave great importance to collective memory, cultural heritage and identity (Bayındır Goularas 2012: 134). Sepetcioğlu (2014) also mentions that the refugees brought with them a different way of dressing, "mantinades", food, a different culture (Sepetcioğlu 2014: 7071 ), issues which this study attempts to present.

\section{Memory and Identity}

In general, through our memory, specific versions of an event can be promoted or silenced (Hodgkin, Radstone, 2003 p 5), depending on the purpose they serve. Hobsbawm, who dealt with the creation of formal traditions in the 19th century, has reported that social groups required new inventions to ensure or express social cohesion, identity and to build social relations (Hobsbawm, Ranger 2004, p 297). The term "fictional tradition" refers to Hobsbawm as a set of practices that seek to introduce certain values and rules of conduct through repetition, which automatically implies continuity of the past (Hobsbawm, Ranger 2004, pp 9-10). In general, collective memory provides a framework, usually through the relevant traditions, in order to understand and interpret the present.

Therefore, from every period in our lives we keep memories that are constantly reproduced, perpetuating through them the sense of our identity (Halbwachs, 2013b, p 118). Thus individual 
and collective identities appear, which are reproduced with the help of memory, through habits and traditions, reinforcing or forgetting aspects of the past. According to Le Goff, since "we are our memories", memory is an essential element of individual or collective identity (Le Goff, 1998, p 143).

The concept of identity is often found in the social sciences humanities' literature, such as customs, traditions, values, relationships, and stories about the past shape our identity (McGrattan, 2013, p 28). According to Abrams, societies display specific identities, which are shaped by both the historical evolution of societies and the oral histories of the individuals living in them. The process of identity formation depends directly on the social structure (Abrams, 1982, p 262). Likewise, Hall has stated about identity that it is always under construction and that we must think of identity as a production that is never complete, but always in progress and always connected with representations (Hall, 1990, p 222).

Every identity is negotiable and open to question, with memory playing a central role in almost all perceptions of identity. As Bell argues, collective identities are the result of myth, memory and politics (Bell, 2006, p 17). Every society needs the corresponding memory to transfer its evolution in time, which does not exist without the active construction of the past to support a given identity (Bartelson, 2006, p 37). For this purpose, mnemonic techniques were developed, which are used in the dissemination of memories ( $\mathrm{p} 38)$.

It is a fact that collective identity of a community needs symbols and patterns (Assmann, 2017, pp 177-9). Patterns are created through selective memory processes, which can reduce at temporary and individual event to a timeless value. We choose from the past an event that is important for the present and determines us. Otherwise, its reminder would have no meaning. The selectivity of our memory is, consequently, connected with the complex and constructed nature of our identities. Personal memories manage to influence both the present and the past, a past that is always subject to change depending on the narration of events and the meaning given to them by individuals. The past, therefore, is in a steady state of transformation (Hodgkin, Radstone, $2003 \mathrm{~b}, \mathrm{p} 23$ ), as is the formation of memories and identities.

The social environment and the people who live in it have an important place in the formation of identities. Over the years, the memories are transformed and, at the same time, the identities that are promoted by the respective social groups are modified and are subject to continuous reconstructions. Memory has a close relationship with the social context, so collective memory reconstructs the various memories to coexist with contemporary ideas and concerns (Halbwachs 1992: 224).

Relatedly, this work aims to investigate how memories of Cretan Turks living in Bodrum shaped their identity and how these memories have been transmitted through different generations in the course of time.

\section{Cretan Turks}

Memories of Cretan Turks of Bodrum were interpreted in the context of the present and defined in relation to it. The individuals invoked a "Cretanism" (kritikotita), on the basis of which they also determined their identity, but without defining its content. As it turned out, many times the memory was identified as a "smuggler" in specific behaviors, in specific foods, in specific appearance and clothing. In Bodrum, Cretan Turks projected a picture of limited economic prosperity, but with high cultural capital. Their identity presented different characteristics to those that identified their ancestors in Crete, where the latter were landowners and affluent.

The first generation of Cretan Turks refugees, as it similarly happened with the people of Asia Minor, experienced the Exchange as a multiple loss, including loss of job, loss of property, loss of place, loss of relative persons. However, unlike the people of Asia Minor in Greece, where the new social environment did not prevent events promoting the identity of Asia Minor, the first 
generation of Cretan Turks in Turkey continued, for many years after settling in the new environment, to have the memories of their homeland suppressed. The image of the homeland, in fact, in many cases, was enlarged and led to its beautification. It was observed that in the last few years, the memories of Cretan Turks have been in demand in Turkey and that there has been an explosion of fictional memories and attempts to connect the present with an unknown, distant past.

In a previous research study in Greece and, in particular, in Heraklion at Crete, descendants of refugees from Asia Minor had pointed out specific characteristics, such as the issue of morality, the institution of the family, housekeeping and hard work (Psaradaki, 2012, pp 96-97. As Zaimakis has also mentioned, the refugees in Greece stressed that the land and the fields were exploited thanks to their own diligence, and the refugees brought knowledge and culture to the locals (Zaimakis, 2008, p 114). In Asia Minor, secondary cultural characteristics (such as hard work, piety, housekeeping, religiosity) acquired a fundamental importance in terms of their selfesteem and the maintenance or formation of an identity. The focus, in fact, on particular features of Asia Minor has been used by them in the present to derive prestige, as the identity of the refugee is now restored and not stigmatized.

In Bodrum, it was found that Cretan Turks, respectively, referred to their distinctive characteristics, which they attributed to their different culture. This different culture is generally carried by refugees, as refugees and other immigrants brought with them new political ideas, art, culture, but also unprecedented habits. Chryssanthopoulou equally mentions the emphasis on superiority (Chryssanthopoulou, 2003, pp 110-111). In particular, she states that individuals selectively develop a national ideology of uniqueness and superiority, resulting from collective representations of their past, in order to accept change and better adapt to new circumstances. According to her book, the people of Kastelorizo convey their national identity, emphasizing its ideological part, their collective representations from the past, which guide them to action and social interaction.

As refugees and other immigrants brought with them new political ideas, art, culture, but also unprecedented habits, it is clear that in Bodrum the designation "Cretan" prevailed and was used as an element of distinction between the Cretan Turks and the local community. For example, a second-generation Cretan Turk often referred sweets as "Cretan", which were offered in all social occasions (weddings, births, funerals). For example, halva, baklava, ravani, kourabiedes.

Many times, along with the characterization "Cretan", the "diversity" of the Cretan Turks was emphasized. This difference was evident even in very simple gestures that, through frequent repetition, became habits and expressions of "Cretanism". More specifically, references to such forms of Cretan Turks performance were found in the following excerpts from interviews:

"Like all Cretan Turks, my father was sitting on the one side of the donkey" (Interview with Mehmet, 09.08.13).

"I knit like the Cretans. [...] That's the way I learned and got used to it from a young age" (Interview with Güler, 23.07.13).

In the second example, it is observed that the different way of knitting, which has to do with the way of holding the needle, is called "Cretan". The knitting needles are held with the three fingers, thus constituting another kind of memory, as "we remember by doing". Knitting can be considered a practice, a habit that we repeat without remembering how or when we learned it (Connerton 2009: 141).

It is no coincidence that Cretan Turks identified themselves as civilized in an environment which, upon their arrival, began to develop. However, what Cretan Turks put forward as a "Cretan" and superior culture seems to have been a mixture of old and new elements, constructions that for individuals referred to Crete. Individual narratives of the past were nothing more than refractions 
of memory, forming the past of individuals (Connerton, 1989, 2009, Halbwachs, 2013b, Kyriakidou-Nestoros 1993).

\section{"I AM CRETAN"}

The designation Cretan prevailed and was used as an element of distinction between Cretan Turks and the locals of Bodrum. References were also often made to Cretan desserts and food produced for all social occasions (weddings, births, funerals). The wedding ceremony of Cretan Turks in general differed from the wedding of the locals as a ceremony and specifically in terms of the custom of dowry. In the latter, the dowry and gifts were transported using camels, a custom that did not exist among Cretan Turks. Also, the dowry in Cretan Turk weddings was distinguished by the variety of its items and the austerity of the decoration. The practice of food was one of the practices used by women to reproduce and transfer memory to future generations. The so-called "Cretan tradition" was mixed with elements of the wider Greek and local Turkish cuisine. References to food were associated with the senses and, in particular, with olfactory memory. Olfactory memory was the one that helped Cretan Turks to remember the "Cretan names" of the ingredients, but also the names of the foods themselves.

In the narratives many times the diversity of Cretan Turks was emphasized. This difference was found even in very simple physical practices that, through frequent repetition, became habits and examples of "cretanism". In fact, through performance, characteristics and aspects of identity are often highlighted:

"Like all Turkish Cretans, my father was sitting crooked [sideways] on the donkey" (Interview with Mehmet, 9 August 2013).

"I knit like the Cretans. [...] That's how I learned and got used to it from a young age, for that" (Interview with Güler, 2 July 2013).

For example, it is observed that the different way of knitting, which has to do with the way of holding the needle, is mentioned as cretan. The knitting needles are held with the three fingers by Cretan Turks, thus constituting another kind of executive memory, as "we remember by doing". Knitting can be considered an embodied practice, a habit that we reproduce without remembering how or when we learned it (Connerton, 2009, p 141). The narratives also pointed out specific features of Cretan Turks:

"The Cretans are coquettish, but not the village women" (Interview with Mustafa, 7 June 2013).

"Our girls were fashionable. They want money for themselves. Years later, the locals wanted to married with them. Why? Because our girls know to take care of the house, the locals do not know" (Interview with Hasan, 31 May 2013).

Some characteristics of Cretan Turk women, in fact, seem to have initially stood as an obstacle to the issue of marriage with locals. In Turkish, local people in Bodrum use the phrase "Giritlilerden k1z alma, k1z ver", which is translated in English as: "Do not take a girl from the Cretans, give them a girl". During the field research, the narrators pointed out that the reason why this phrase appeared was because Cretan Turks were more modern and well-groomed than the locals and that is why it was difficult for husbands of Cretan Turk women to support them financially. Mansur points out, respectively, the different attitudes between Cretan Turks and local women in Bodrum, stating that local women were more disciplined towards their husbands. The Cretans were more eloquent and more independent in their movements (Mansur, 1972). This was probably another reason, that local women married with Cretan Turks while the opposite did not happen: 
"The locals used to say that if you want to marry a Cretan girl you have to have a lot of money to feed her. Because the Cretan girl wants to come back" (Interview with Al1, 12 June 2013).

"The locals did not want to take the Cretans because they were more modern, more wasteful, they spent money. But they wanted to give girls to Cretans because the women took care of them" (Interview with Canan, 05 June 2013).

"My wife is Cretan. Cretans here are modern" (Interview with Hüseyin, 01 June 2013).

"The outfit was different. Locals wore salvari (breeches). Cretans did not wear it" (Interview with Elvan, 09 July 2015)

"Cretans are modern. A Cretan woman and a local with the same clothes next to each other, Cretan woman is different. [...] I am Cretan and I am proud. I'm different. In my opinion, there is still a difference at being Cretan" (Interview with Güler, 05 September 2015).

According to the narrators, the differences in the appearance of local and Cretan Turks women were also significant. Cretan Turks are characterized as more well-groomed and modern than locals and the "Cretan appearance" was considered superior to the locals. It is also observed that individuals form a dipole of "us" and "others", which is not determined in relation to educational level or social status, but mainly with respect to external characteristics of appearance and general behavior.

Testimonies are approached as imaginary reconstructions and not as facts. In general, testimonies help to examine the way in which "Cretanism" is formed and which focuses on specific features of Cretan Turks, such as their beauty and careful appearance. It is also noteworthy that Cretan Turks in Bodrum are presented with characteristics very different from those that distinguished women in Crete before the Exchange.

Taking inspiration from the references of Cretan Turks to their "Cretan identity", the narrators in Bodrum referred to a "Cretan culture", part of which they considered to be themselves, but without being able to give this culture a clear content:

"Ifeel lucky that I am from Crete. Because Cretan Turks are open-minded, required mentality" (Interview with Nilay, 05 June 2013).

In the case of Cretan Turks, it seems that attitudes or characterizations of "cretanism" were memorized, which were not imposed by state policies, but were shaped by them. Specifically, Cretan Turks followed the standards of their ancestors and the characteristics of Cretans that they transmitted to them and continued to project these features in their speech and daily life. Individuals, therefore, not only narrated the events, but at the same time identified themselves with them.

It also seems that many Cretan Turks learned to be called "Cretans" by their parents. Next generations continued to be called Cretans, having the modern characteristics and the diversity of being Cretan, as elements of a recognizable stamp, which they had on them.

In general, we would say that the adoption of a series of positive stereotypes by Cretan Turks was a kind of defense against the negative criticism, which both them and their ancestors accepted at the new place of installation. People have often used the first-person plural in phrases such as "we taught them", "we are different", "this is how we, Cretans, cook", trying to keep up with the past. This behavior refers to what Connerton has pointed out about the actions that are performed, under the illusion that these actions remain the same over time. By denying individuals the time distance, they point to the existence of the same, true and authentic reality (Connerton, 1989, p 
43). The narrators idealized the past, based on the needs of the present, transforming their memories accordingly.

\section{The Nicknames of Cretan Turks in Bodrum}

During the research in Bodrum, it was found that among Cretan Turks the nicknames had a special place and contributed to the formation of their identity. Nicknames, like adjectives, were an element of identity for individuals. They were usually given to individuals and were in agreement with the identity, history and reputation of the person nicknamed. As Tsimouris has mentioned, nicknames were often necessary to understand who the person was and sometimes nicknames even had a derogatory meaning (Tsimouris, 1997, p 179). It should also be noted that the nickname is a name that is used in the oral speech, in contrast to the family name, which is mainly used in the written speech (Tsantiropoulos, 2004, p 170).

A nickname can be produced in many ways. It can be related to a profession, a title, the place of origin, a word or a verbal corruption, the meaning of which is usually forgotten and remains unknown to the person who bears the specific nickname (Tsantiropoulos, 2004, pp 168-171). According to Tsimouris, the nickname can be a reminder of a particular feature of a person's appearance, character or habits. It may be a joke or a turning point in his life or a specific professional activity (Tsimouris, 1997, p 179). Many nicknames, may not be flattering or refer to a funny aspect of an individual's personality (Herzfeld, 2012, pp 285-286).

In the context of the dissertation, the collection and recording of nicknames of Cretan Turks aimed at identifying the type of characteristics they transmitted to individuals. The nicknames that were collected came from oral testimonies or written reports and their recording were largely completed with the help of the archive kept by a second generation of Cretan Turks. Although most of the nicknames were not active during the investigation, a total of sixty-four nicknames were recorded in Bodrum. Many of them had the well-known derogatory ending "-aki", which is found in adjectives of Cretans even today. Cretan Turks, from July 1934, acquired Turkish surnames, after the imposition of a family name on the Turks by Kemal ${ }^{3}$ (Kefalakis, 2010, p 22).

Nicknames collected were sorted by meaning, as shown in the table below.

\begin{tabular}{|c|c|c|c|c|}
\hline \multicolumn{5}{|c|}{ Nicknames of Cretan Turks in Bodrum } \\
\hline $\begin{array}{l}\text { origin from part } \\
\text { of Crete }\end{array}$ & $\begin{array}{c}\text { job / quality / } \\
\text { habit }\end{array}$ & $\begin{array}{l}\text { characterization } \\
\text { (with positive } \\
\text { meaning) }\end{array}$ & $\begin{array}{l}\text { characterization } \\
\text { (with negative } \\
\text { meaning) }\end{array}$ & $\begin{array}{l}\text { Unknown } \\
\text { meaning }\end{array}$ \\
\hline $\begin{array}{l}\text { Akolanos } \\
\text { Kavusanos } \\
\text { Kefalanos }\end{array}$ & $\begin{array}{l}\text { Barbarasaki } \\
\text { Fandaros } \\
\text { Furnaru } \\
\text { Karaviti } \\
\text { Kopanaki } \\
\text { Kurmuli } \\
\text { Kukaçi, Kuçi } \\
\text { Lathas, Latho } \\
\text { Makromalusa } \\
\text { Nalbantaki } \\
\end{array}$ & $\begin{array}{l}\text { Arnaçi } \\
\text { Ayeraçi } \\
\text { Betis } \\
\text { Cirita } \\
\text { Habibaçi } \\
\text { Malama } \\
\text { Mustakaçi } \\
\text { Spita } \\
\text { Sakranos } \\
\text { Vapora } \\
\end{array}$ & $\begin{array}{l}\text { Arfanus } \\
\text { Çoli } \\
\text { Dalavera } \\
\text { Htipa } \\
\text { Fafulaki Fafuti } \\
\text { Kampuraçi } \\
\text { Karpuzaki } \\
\text { Karinas } \\
\text { Kasithis } \\
\text { Kasoçeras } \\
\end{array}$ & $\begin{array}{l}\text { Biraki } \\
\text { Çillas } \\
\text { Çuri } \\
\text { Hahami } \\
\text { Halazari } \\
\text { Harharus } \\
\text { Fantaçi } \\
\text { Fulaka } \\
\text { Mavruka } \\
\text { Mlamlakos } \\
\end{array}$ \\
\hline
\end{tabular}

\footnotetext{
${ }^{3}$ Because the previously used titles and nicknames were used to cover all the members of the society, they caused some confusion in the official records of the state about trading, tax and military service. This has often caused irreparable damage to the state and individual. For this reason, the aim was to determine a pure Turkish surname that would be taken by the head of the family and used by the family members, as in western societies.

The "Law on Surnames" was adopted on June 21, 1934 as a result of the negotiations held in the Grand National Assembly of Turkey and the law was implemented throughout Turkey on January 2, 1935.
} 


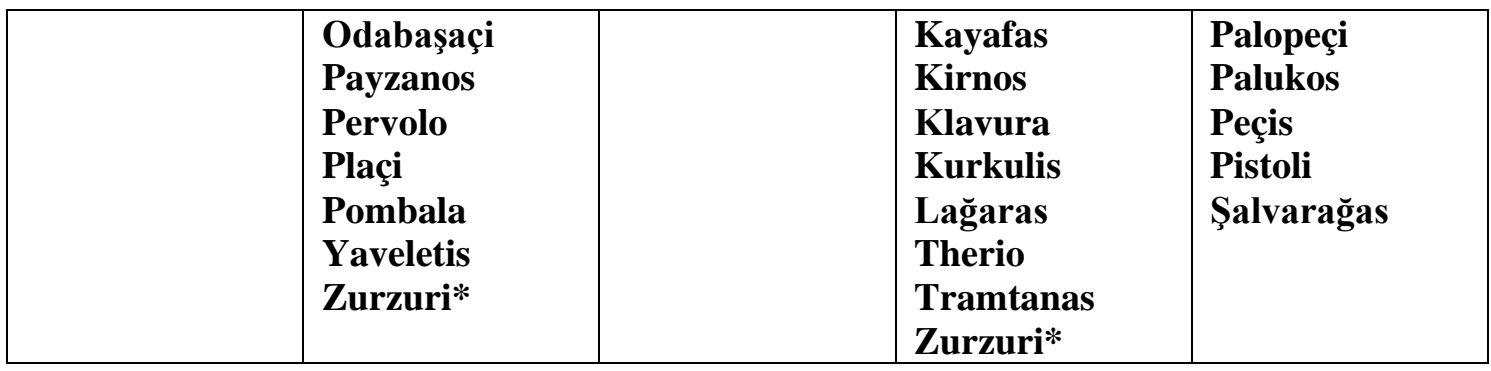

*Due to its dual meaning, the word is considered to be related to a job but also to a negative characterization.

The variety of nicknames highlights the number of features that there was a desire to emphasize. It is also observed that many nicknames had the same suffix as the adjectives that exist in Crete in "-akis", a suffix that, according to Adiyeke, first appeared in the adjectives of Crete in the period between 1820-1824 (Adiyeke, 2015, p 106). Tzedaki-Apostolaki states in this regard that the patronymics themselves come from the addition of the productive suffix -akis, the use of which was present in the island from the beginning of the 19th century, to the subject of the name of the ancestor and appears stable (Tzedaki-Apostolaki, 2005, p 45).

After classifying the nicknames in the above categories and assuming a possible interpretation of their meaning, it appeared that most of the nicknames referred either to external characteristics (projecting a specific point of appearance, more often in a negative way), or to manual labour jobs, which referred to lower social strata, such as that of the fisherman, the horseman or the worker. Only three were nicknames, which clearly referred to the place of origin, having the suffix "-anos", a suffix that is still found in Crete, to indicate the village of origin.

Oral testimonies indicated that the nicknames preceded the Exchange. However, many of them seem to have been created later, especially those whose root or ending is not found in Crete. Several nicknames, however, appear in families of residents of Crete at present. Indicatively, the Paizanos (farmer), Karavitis, Kampourakis, Karpouzakis, Kopanakis, Kourmoulis, Nalbantakis, Fafoulakis are Cretan adjectives. This identification of several nicknames with Cretan adjectives probably indicated a kinship relationship, which was indirectly transferred through the nickname to the new place of establishment.

The nicknames, however, accompanied the first-generation refugees and were kept mainly as a memory during the research. Although an attempt was made to identify their meanings, in most nicknames this was not possible. Due to the fact that they were only verbally communicated, many nicknames had linguistic errors and no syllable correction was attempted, as it may have led to incorrect changes and meanings. In several nicknames, however, the narrators knew their meaning, as shown in the following passage:

"My grandfather was nicknamed platçı. Does it mean anything in Cretan? They said it because he had big feet and made noise while walking" (Interview with Canan, 05 June 2013).

In addition to the nicknames that were older and were owned by first- and second-generation refugees, newer nicknames also appeared. During an interview with a fourth generation Cretan Turk, he had added the Cretan suffix "-akis" to the Turkish word berber and was known as "Berberakis". In his interview the person stated:

"My nickname is Berberakis. [...] Cretans use nicknames. My friends, also Cretans, called me like that. And I used it in the barber shop. They really liked it. They see it and ask me if I have a relationship with Crete. And I tell them the story. It's a part of me. I feel Cretan. Both my parents are Cretans" (Interview with Bayram., 06 August 2015). 
It can be said that names such as "Berberakis" can be a family name and not only a nickname (For these issues there are helpful studies such as Menekşe, 2015, Sepetçioğlu, 2011). "Cretanism", in this case, is used by the narrator as a positive characteristic, acting as an advertisement, in the context of the general positive use of the term "Cretan" in Bodrum.

\section{RESULTS AND CONCLUSION}

The Population Exchange of 1923 between Greece and Turkey remains an important subject of research for different sciences, including Cultural and Social Sciences and Social Anthropology. The ethnographic work presented in this article, includes social oral memories and identity of a refugee group, the one of Cretan Turks.

Several key claims have been used; in particular, the theory of the social framework of memory, which was supported by Halbwachs, as well as the methods of transferring memory and its multiple versions, which Connerton stated. There is a distinction between individual and collective identity, as both their complexity and the formation of identities were the result of choices that often-served specific purposes and created fictional traditions (the term is by Hobsbawm).

Particularly, the memories of the place of origin and the ways of remembering at present, the concepts of memory and identity were the theoretical schemes which have been used. The formal and informal ways of memory preservations were investigated and, furthermore, the way of making contemporary social identities was examined. Methodologically, the research involved data coming from the participation in group events, interviews as well as archive research. Secondary sources included research on the area, newspaper articles, books by local authors about Bodrum, or biographies of its inhabitants. (Koparanoğlu 2006, Mansur 1972, 2015, Oran - Görgün 2009, Tanrı̈ver 2011).

Carrying out the first field research in Bodrum, it was noticed from the very beginning that the narrators stressed the similarity between Cretan Turks and Cretans in certain characteristics and the common sense of hospitality. A common characteristic between them, was the use of the "Cretan dialect" by descendants of the second generation of Cretan Turks. Many of them remembered and expressed themselves with the word Cretan or with a nickname. This behavior was also present by those who could not speak Cretan, the third-generation descendants who had a strong desire to talk about a past that had marked their memory.

In any case, the memories of individuals both affect and are affected by the present. Memory is largely a reconstruction of the past with the help of data we borrow from the present, a reconstruction which has been created by other reconstructions in previous eras and from which the image of the past has already emerged altered. Thus, many of the memories which we believe that we have kept intact are almost entirely shaped by false identities based on narratives and testimonies (Halbwachs, 2013, pp 94-96).

Cretan Turks shaped and continue to shape their memories based on new events and memories, which they homogenize and present as authentic and continuous from generation to generation, emphasizing the preservation of continuity. For the first-generation refugees, the designation "Cretan" included Crete as a place of birth, "Cretan dialect" as a spoken language and specific behaviors as daily practices. Although Cretan Turks interacted and merged with the local population, it is found that they continue to promote their "Cretan origin", giving positive features to what they define as "Cretan culture".

Many Cretan Turks learned to be called Cretans by their parents and the present generations continue to call themselves Cretans, having the modern characteristics and the difference of being 
Cretan, as elements of a recognizable stamp that they bear on them. During interviews with descendants of Cretan Turks, people often began with the phrase "I am Cretan".

Although the fourth-generation Cretan Turks seemed more distant from the past, they kept strong the feelings of pride and preserved a unique culture that distinguishes them, in several ways. This difference was expressed by examples of eating habits, clothing, employment, entertainment that initially distinguished Cretan Turks from the locals. Such examples were the eating habits of the former, the most modern way of dressing.

Invitations and subsequent visits to the houses of Cretan Turks helped to highlight an additional, rich background on the importance of memory. In particular, "Cretan identity" was felt in nicknames that functioned as "bridges of memory" between the present and the past.

At the same time, through the narratives of Cretan Turks, many common elements with the Asia Minor were revealed. A separate reference was made to their treatment by the locals. Cretan Turks had an additional reason for not preserving the "Cretan language", which they were forced not to use. However, they found ways to preserve and transmit elements of their "Cretan identity", as they have used and continue to use some extent practices related to what is defined as "Cretan". Food, the ways of cooking and its ingredients were such examples.

Over the years the communication with the local population has increased both in the professional and personal sector. Cretan Turks were a workforce that strengthened the economy of the region and the employment of many Cretan Turks in particular in maritime professions contributed to the development of this sector, creating a tradition in these professions (captains, sailors, spongers, fishermen). The daily interaction with the locals also led to the gradual beginning of weddings between locals and Cretan Turks.

At present, so many years after the Exchange and having to deal with factors such as time that does not help preserve memory but instead enhance oblivion, Cretan Turks of Bodrum manage to insist on projecting a distinct "Cretan identity". As present depends on and is a continuation of the past, it is not only the need to project this past as an element of their identity in every age that deserves special attention, but it is also important the reason why everything is chosen to be projected.

\section{REFERENCES}

Adıyeke, N. (2015) “Girit’te Müslüman ve Gayrı Müslim Cemaatin Ortak Kimliği: Aile Adları”, Geçmişten Günümüze Girit. Tarih - Toplum - Kültür, Uluslararas1 Sempozyum, 16-18 Ekim 2015, Kuşadası: Kuşadası Belediyesi, Kuşadası Giritliler Derneği.

Akça, B. (2011) “20.yy. Başında Bodrum Kazası”, 2. Uluslarası Her Yönüyle Bodrum Seтроzуити, 9-12 Mayıs 2011, Bodrum Belediyesi.

Altınsay, S. (2008) My Crete, Athens: Kedros (in Greek).

Assmann, J. (2017) Cultural Memory. Writing, Memory and Political Identity in the Early Higher Civilizations, Heraklion: University Publications of Crete (in Greek).

Bartelson, J. (2006) "We Could Remember It for You Wholesale: Myths, Monuments and the Constitution of National Memories" in Bell D. (ed) Memory, Trauma and World Politics. Reflections on the Relationship Between Past and Present, Palgrave Macmillan: New York, pp. 33-53.

Bayındır Goularas, G. (2012) "1923 Türk-Yunan Nüfüs Mübadelesi ve Günümüzde Mübadil Kimlik ve Türklerinin Yaşatılması", Alternatif Politika, Cilt. 4, Temmuz Sayı. 2, 129-146. 
Baykara, A. (2010) XIX. Yüzyıl Bodrum Kazası'nın Sosyal ve İktisadi Hayatı, Ege Üniversitesi Sosyal Bilimler Enstitüsü, İzmir.

Bedlek, E. (2016) Imagined Communities in Greece and Turkey. Trauma and the Population Exchanges under Atatürk, I.B.Tauris \& Co. Ltd, London, New York.

Bell, D. (ed.) (2006) Memory, Trauma and World Politics. Reflections on the Relationship Between Past and Present, Palgrave Macmillan: New York.

Chalkiadakis, E. (2013) Crete, 1898 - 1913. From "Autonomy" to the Union with Greece, Heraklion: Region of Crete, (in Greek)

Chryssanthopoulou, V. (2003) "Gender, Work and Ethnic Ideology: Castellorizian Greeks in Perth, Australia", The Greek Review of Social Research, 110, pp.107-140.

Connerton, P. (1989) How Societies Remember, Cambridge: Cambridge University Press.

Connerton, P. (2009) How Modernity Forgets, Cambridge: Cambridge University Press.

Çapa, M. (2011) "Yirminci Yüzyılın başlarında Bodrum”, 2. Uluslarası Her Yönüyle Bodrum Sетроzуити 9-12 Mayıs 2011, Bodrum Belediyesi.

Çokişler, N. (2007) Girit Göçmenleri Türk Halk Kültürü̈ Üzerine Bir Araştırma, Ege Üniversitesi Sosyal Bilimler Enstitüsü, İzmir.

Erkal, A. (2008) Girit. Geleneksel Kültürüyle Türk, Üçüncü Kitap, İzmir: Nurdaş.

Güler, I. (2011) “XIX. Yüzyıl İkinci Çeyreğinde Bodrum'da Nüfus Hareketleri: Bir Yoklama Defteri’nin Düşündürdükleri”, 2. Uluslarası Her Yönüyle Bodrum Sempozyumu 9-12 Mayıs 2011, Bodrum Belediyesi.

Halbwachs, M. (1992) On Collective Memory, London: University of Chicago Press.

Halbwachs, M. (2013) The Collective Memory (translated by Tina Plyta), Athens: Papazisis publications, (in Greek).

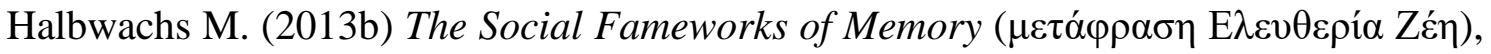
A $\theta \eta ் \vee: ~ \varepsilon \kappa \delta o ́ \sigma \varepsilon เ \varsigma ~ N \varepsilon \varphi \varepsilon ́ \lambda \eta$.

Hall, S. (1990) 'Cultural Identity and Diaspora' in J. Rutherford (ed), Identity: Community, Culture, Difference, London: Lawrence \& Wishart, pp.222-237.

Herzfeld, M. (2012) The Poetry of Manhood. Competition and Identity in a Mountain Village of Crete, Kioseoglou Nerina (ed), (translated by Kastanara Maria), Athens: Alexandria publications, (in Greek)

Hobsbawm, E. Ranger, T. (ed.) (2004) The Invention of Tradition, (translation by Athanasios Thanasis), Athens: Historical Library, Foundation (in Greek).

Hodgkin, K., Radstone, S. (2003) Contested Pasts. The Politics of Memory, Hodgkin K. Radstone S. (ed.), Routledge: London and New York.

Kodal, T. (2008) “Atatürk Döneminde Bodrum'un Nüfus Yapısı (1923-1938)”, Sosyal Bilimler Dergisi 17, 77-100.

Konya, D. (2013) Sosyal, Siyasal ve Ekonomik Yönleriyle Bodrum (1930-1960), Muğla Sitk1 Koçman Üniversitesi Sosyal Bilimler Enstitüsü, Muğla.

Koparanoğlu B. (2006) Karşı Kıyılardan Bodrum'a, İstanbul: Altın Kitaplar. 
Kyriakidou-Nestoros, A. (1993) Folklore Studies II, Skouteri-Didaskalou Nora, Delopoulos Kyriakos., Kairi Maria (ed.), Athens: Poreia (in Greek).

Le Goff, J. (1998) History and Memory, Athens: Themelio, (in Greek).

Limantzakis, G. (2015) The Cretan Turks and the Cretan Issue: from the Late Turkish Occupation to the Union, Chania: Ereisma, Center for Asia Minor and Pontian Studies (in Greek).

Mansur, F. (1972) Bodrum: A Town in the Aegean, Leiden: Netherlands.

McGrattan, C. (2013) Memory, Politics and Identity. Haunted by History, Palgrave Macmillan: UK.

Oran B.- Görgün F. (2009) Dalavera Memet’in Bodrum Tarihi, İstanbul: İletişim.

Psaradaki, E. (2012) Memories of Asia Minor Refugees Living at Nea Halikarnassos, in Heraklion, Crete, Master Thesis, Rethymno, (in Greek).

Psaradaki, E. (2020) Memories of Homelands of Cretan Turks in Bodrum, Turkey, Ph.D, Rethymno, (in Greek).

Sepetcioğlu, T. (2007) Cumhuriyetin Illk Ylllarında Girit'ten Söke’ye Mübadele Öyküleri, Adnan Menderes Üniversitesi Sosyal Bilimler Enstitüsü, Aydın.

Sepetcioğlu, T. (2010) “Türkiye'de Ana Dili Türkçe Olmayan Göçmen Topluluklara Yaklaşımlara Dair Bir Örnek Girit Göçmenleri”, ÇTTAD, IX/20-21, 77-108.

Sepetcioğlu, T. (2011) Girit'ten Anadolu'ya Gelen Göçmen Bir Topluluğun Etnotarihsel Analizi: Davutlar Örneği, Doctoral Thesis, Ankara Üniversitesi Sosyal Bilimler Enstitüsü Halkbilim Anabilim Dal1.

Sepetcioğlu, T. (2014), "Iki Tarihsel 'Eski' Kavram, Bir Sosyo-Kültürel 'Yeni' Kimlik: Mübadele Nedir, Mübadiller Kimlerdir?”, TSA/YIL: 18, 3, Ocak, 49-83.

Şenesen, R. (2012) Çukurova Bölgesi Girit Göçmenlerinin Girit'e Dair Anlatılarının Sosyal Tarihe Kaynaklık Etmesi, Türk Dili ve Edebiyatı Bölümü, Türkoloji Sempozyumu Bildirileri, Adana.

Tanriöver, S. (2011) Traditional Architecture of Bodrum: The Factors Generating and Affecting the Architectural Cuture and Identity, Intercultural Understanding.1, 79-87.

Tsantiropoulos, A. (2004) The Vendetta in Contemporary Mountainous Central Crete, Athens: Plethron.

Yorulmaz A. (2005) Children of the War. From Crete to Aivali, Athens: Omega, (in Greek).

Zaimakis, G. (2008) Prosperous origins in Lakko, Heraklion. Deviation, Cultural Creation, Anonymous Rebetiko (1900-1940), Athens: Plethron (in Greek).

Fieldwork Interviews Recorded by the Author (the names are substitute names)

Interview with Bayram, born in Bodrum in 1977, hair dresser; recorded 06 August 2015.

Interview with Al1, born in Bodrum in 1943, retired businessman; recorded 12 June 2013.

Interview with Canan, born in Bodrum in 1979, businesswoman; recorded 05 June 2013.

Interview with Hüseyin, born in Bodrum in 1943 retired businessman; recorded 01 June 2013. 
Interview with Elvan, born in Bodrum in 1943 businesswoman; recorded 09 July 2015.

Interview with Nilay, born in Bodrum in 1943 businesswoman; recorded 06 August 2015.

Interview with Güler, born in Bodrum in 1948 housewife; recorded, 05 August 2015.

Interview with Mehmet, born in Bodrum in 1951, mayor; recorded, 9 August 2013.

Interview with Mustafa, born in Bodrum in 1936, seaman; recorded 7 June 2013.

Interview with Hasan, born in Bodrum in 1932, retired businessman; recorded 31 May 2013. 